\title{
Educational Probation Under the Tutorial System and the Construction of English Student Teachers’ Knowledge
}

\author{
WANG Ming-mei \\ Sichuan University of Arts and Science, Dazhou, China
}

\begin{abstract}
This paper attempts to explore effective ways of educational probation to promote the professional development of English student teachers. An empirical study is carried out to compare the teachers' knowledge level of 91 normal students under three different educational probation modes: tutorial system, non-tutorial system, and routine system. Quantitative analysis shows that except English knowledge, the tutorial system is more conducive to promoting normal students' mastery of educational theory knowledge, general curriculum knowledge, English curriculum knowledge, English teaching knowledge, and students' knowledge, and the development of these kinds of knowledge is relatively balanced. This study is helpful for teacher educators to provide guidance and help for pre-service English teachers to maximize the benefits of educational probation.
\end{abstract}

Keywords: tutorial system, educational probation, English student teachers, teachers’ knowledge

\section{Introduction}

Compared with the past, the English environment in China has been greatly improved, but students still have few opportunities to contact English in their daily life. Apart from the English classroom in schools, they generally cannot enter the real English environment. Especially in the stage of basic education, English learning is mainly classroom learning, and most of the English input comes from teachers. Teachers' professional qualities directly affect the result of English teaching, and then affect the overall quality of English education in China (Liu, 2017). The retirement of old teachers and the joining of new teachers make the overall level of teachers change dynamically. Systematic and scientific pre-service teacher training is the key to promote the sustainability of English education in China. Pre-service teacher training is the initial stage of teacher education, which determines the professional development and growth of future teachers. In China, teachers' colleges and universities shoulder the important task of pre-service teacher training. English teaching and teaching practice are the main subjects of English education courses in normal universities (Zhang \& Wang, 2000). However, due to the lack of professional pertinence in curriculum design and the lack of scientific and reasonable teaching methods, the graduates of English teachers' major are not all qualified English teachers (Cheng \& Sun, 2010). Some scholars have explored its causes. Wang Qiang and others investigated the present situation of pre-service education of foreign language teachers in China. They found that the teaching method courses did not really enable students to apply what they learned, and students had fewer opportunities to practice (Wang,

Acknowledgements: The research is supported by the 9th China Foreign Language Education Fund (No. ZGWYJYJJ2018B100) and Education and Teaching Research and Reform in Sichuan University of Arts and Science (No. 2017JY13).

WANG Ming-mei, M.A., associate professor, School of Foreign Languages, Sichuan University of Arts and Science, Dazhou, China. 
Tian, Qian, \& Yuan, 2007). Zhao Xiao-jun, after instructing graduates to practice, proposed that the training time and practice time of students' teaching skills in school are too short and should be increased (Zhao, 2006). Wan Ming-gang (2005, p. 87) held that the direct cause of impacting the professional quality of normal students is the disconnection between normal education and basic education, the short time of teaching practice, the lack of conditions and opportunities for normal students to understand the actual teaching situation in the basic education stage, which leads to the neglect of thinking and analyzing the problems existing in the practical teaching of normal students.

Teacher training has a strong practicality (Liu \& Zou, 2009). The cultivation of pre-service teachers' professional quality requires not only the instillation of teaching theoretical knowledge, but also the understanding of real teaching in specific classroom environment. Through interaction with students, classroom, teaching environment, and other factors, abstract theoretical knowledge is internalized to form specific personal practical knowledge. With the deepening of teacher education reform, many colleges and universities have added educational probation courses, which become an important part of normal students' teaching practice, forming a transitional link between theoretical learning and educational practice. Normal students can gain practical experience through educational probation and practice. Therefore, how to arrange educational probation to help pre-service English teachers get the greatest benefits has become a question for us to think about.

\section{Teachers’ Knowledge}

Teachers' knowledge is the core of teachers' professional quality. It is all the knowledge and skills that teachers master for effective classroom teaching. It determines the quality of teachers' teaching and students' learning. The study of teachers' knowledge abroad originated from the discussion of effective teaching knowledge of teachers in the 1960s. Since the 1980s, it has been a frontier and hot issue in the study of Teacher Education in the West. After years of development, research methods and contents have changed greatly, and the focus of research has gradually expanded from teachers' internal knowledge system to the influence of external teaching and social situations on teachers' knowledge. Domestic research in this field began in the 1990s, mainly focusing on literature review and theoretical discussion. As for the question of "What is teachers' knowledge”, the most representative and influential answer is Shulman's (1987) classification according to content. He believes that teachers' knowledge should include seven categories: subject content knowledge, general pedagogical knowledge, curriculum knowledge, subject pedagogical knowledge, student knowledge, educational situation knowledge, and other curriculum knowledge. Ma Yun-peng, a domestic scholar, drew lessons from Shulman's research and put forward the basic framework of teachers' knowledge based on the actual teaching situation in China, and gave a specific definition (Ma, Zhao, Han, Song, \& Zhao, 2008). They believe that qualified teachers should have the following four kinds of knowledge: educational theory knowledge, curriculum knowledge, subject knowledge, and subject teaching method knowledge. Educational theory knowledge refers to the basic principles of education, common teaching methods, basic educational psychology knowledge, etc. Curriculum knowledge refers to the knowledge of curriculum objectives, curriculum structure, curriculum contents, and teaching methods of a specific subject. It mainly includes two parts: the general curriculum knowledge about the basic education curriculum reform and the subject curriculum knowledge specific to a certain discipline. Subject knowledge refers to the concepts, principles, and methods of a specific subject. As far as English is concerned, it refers to English teachers' knowledge of 
English grammar, vocabulary, linguistics, western literature and culture. Subject teaching method knowledge refers to the comprehensive use of the above three kinds of knowledge by teachers so as to transform subject knowledge into knowledge easy for students to understand and accept. Student knowledge includes students' characteristics and cognition, students' development and motivation. Only when teachers master the student knowledge can they prescribe the right medicine to the right situation and improve the teaching efficiency. Otherwise, they are playing the piano to the ox and not pleasing to the effort. Therefore, student knowledge is an indispensable part of teachers' knowledge. In view of this, this study adds student knowledge to the type of teacher knowledge proposed by Ma Yun-peng and others as a test item.

In recent years, undergraduate tutorial system has been implemented in some universities and achieved good results. The author tries to incorporate educational probation into the tutorial system so that English teachers can conduct educational probation under the guidance of teachers, and makes an empirical study of its effectiveness.

\section{Research Method}

\section{Research Questions}

(1) Can the educational probation under the tutorial system effectively improve the teachers' knowledge level of English normal students?

(2) If so, is the development of all kinds of knowledge balanced?

\section{Research Objects}

This study was conducted in three parallel classes of the third grade of English education major in a comprehensive university in Sichuan Province. All three classes began to learn pedagogy and psychology from the fifth semester, and the teachers are the same. All three classes will take part in a six-week internship in the eighth semester, of which the first two weeks are probation.

\section{Research Design}

Class 1 was randomly selected as the experimental class (30 students); three students and one instructor formed a group. The two additional weeks of probation were arranged in the 6th and 7th semesters respectively, one week in each semester, and 2-3 middle school teachers' English class were observed every week. In the first two weeks of in-depth middle school probation, students, with the help of tutors, made detailed teaching plan design for the teaching unit, including teaching focus, teaching steps, classroom activities, and after-class tasks. The tutor participated in the whole process of the probation. In order to re-study classroom teaching after returning to school, each group recorded the teaching of the probation class. At the end of the probation, an exchange meeting was held in time. The instructor led the students to make a thorough and detailed analysis of classroom videos from the macro (such as educational concepts and teaching methods) and micro (such as classroom terminology, accident handling, etc.) perspectives, to compare and summarize the strengths and weaknesses of different middle school teachers, as well as the teaching changes of the same teacher during repeated teaching in different classes, then discussed and revised the design of the teaching plan before the probation. Finally, according to the specific situation of each student, the tutor assigned tasks such as reading bibliography after class, basic skills training in English teaching, teaching plan design and so on, and also checked the completion of the tasks. Class 2 (31 students) was the control class A. There were also two weeks of probation in the 6th and 7th semesters, but there was no teacher's participation and guidance. Class 3 (30 
students) was the control class B, and only participated in the two-week routine probation before the 8th semester internship.

\section{Research Tools}

In this study, self-compiled test papers were used as survey tools. The test paper mainly examines teachers' knowledge in the following six aspects: educational theory knowledge; general curriculum knowledge; English curriculum knowledge; English knowledge; English teaching knowledge; and student knowledge. Details of the propositions are given in Table 1.

Table 1

English Student Teachers' Knowledge Testing Propositions

\begin{tabular}{|c|c|c|c|c|}
\hline Knowledge type & Question type & $\begin{array}{l}\text { Number } \\
\text { of questions }\end{array}$ & Score & Samples \\
\hline Educational theory & choice & 8 & 8 & $\begin{array}{l}\text { Educational content is a common understanding between } \\
\text { educators and educatees. A. Subject B. Object C. Subject D. } \\
\text { Subject of Doctrine }\end{array}$ \\
\hline General curriculum & judgement & 4 & 4 & $\begin{array}{l}\text { Teaching evaluation under the new curriculum concept } \\
\text { should be diagnostic and formative. () }\end{array}$ \\
\hline English curriculum & judgement & 8 & 8 & $\begin{array}{l}\text { The contents and objectives of English curriculum standards } \\
\text { for senior high schools mainly include language knowledge } \\
\text { and language skills. () }\end{array}$ \\
\hline English & $\begin{array}{l}\text { reading comprehension } \backslash \\
\text { translation }\end{array}$ & $20+5$ & $\begin{array}{l}40+ \\
15\end{array}$ & $\begin{array}{l}\text { Chinese-English translation: 她的身体糟糕到了冬天都不 } \\
\text { 敢见太阳, 免得中暑。 }\end{array}$ \\
\hline English teaching & $\begin{array}{l}\text { choice and Short } \\
\text { Answer Questions }\end{array}$ & $5+2$ & $5+10$ & $\begin{array}{l}\text { Which of the following activities can be used to check } \\
\text { students' understanding of difficult sentences in the passage } \\
\text { A. Explanation B. Fill in blanks C. Storytelling D. Summary }\end{array}$ \\
\hline Student & Short Answer Questions & 2 & 10 & What factors should be considered in cooperative learning? \\
\hline
\end{tabular}

\section{Testing and Scoring}

This study adopted the method of centralized testing. During the test, members of the project team guided and supervised the whole process. The test time was about one hour. After the questionnaires were withdrawn, the questionnaires with too many vacancies were excluded. Before scoring, the scorers were instructed about the scoring criteria and rules, and trained with sample questionnaires to ensure the consistency of scoring.

\section{Data Collation and Analysis}

SPSS 21.0 for windows was used to input and manage data. Descriptive statistical analysis was made on the five kinds of knowledge of the experimental class and the two control classes. The score rate and average score were used as evaluation indexes. One-way ANOVA was used to test whether there were differences in knowledge among the three classes, and multiple comparison test was used to compare the knowledge levels of the three classes.

\section{Results}

Generally speaking, the three classes are equally proficient in English knowledge, with a scoring rate of more than $72 \%$. But in other kinds of knowledge, the gap between the three classes is obvious, and shows a gradient downward trend: The overall level of the experimental class is the highest-the scoring rate of all kinds of knowledge is about $60 \%$; the control class $\mathrm{A}$ is next-the scoring rate is about $50 \%$; the control class $\mathrm{B}$ is the lowest-the scoring rate is about $45 \%$. 
One-way ANOVA analysis shows that there are no significant differences in English knowledge among the three classes, but there are significant differences in educational theory knowledge, general curriculum knowledge, and student knowledge, while there are very significant differences in English curriculum knowledge and English teaching knowledge (as shown in Table 2).

Table 2

Teachers' Knowledge Scores and Difference Test

\begin{tabular}{llllllll}
\hline Class & Knowledge type & $\begin{array}{l}\text { Educational } \\
\text { theory }\end{array}$ & $\begin{array}{l}\text { General } \\
\text { curriculum }\end{array}$ & $\begin{array}{l}\text { English } \\
\text { curriculum }\end{array}$ & English & $\begin{array}{l}\text { English } \\
\text { teaching }\end{array}$ & Student \\
\hline \multirow{2}{*}{$\begin{array}{l}\text { Experimental } \\
\mathrm{N}=30\end{array}$} & Scoring rate & $62.84 \%$ & $60.51 \%$ & $63.87 \%$ & $72.53 \%$ & $57.02 \%$ & $59.11 \%$ \\
& Mean & 5.03 & 2.42 & 5.11 & 21.76 & 4.11 & 3.61 \\
& S.D. & 1.82 & 0.81 & 1.93 & 4.78 & 1.93 & 1.51 \\
\hline \multirow{2}{*}{ Control A } & Scoring rate & $54.86 \%$ & $47.63 \%$ & $51.28 \%$ & $72.18 \%$ & $51.78 \%$ & $52.17 \%$ \\
$\mathrm{~N}=31$ & Mean & 4.51 & 1.56 & 4.02 & 21.71 & 3.76 & 3.13 \\
& S.D. & 1.33 & 0.87 & 1.52 & 5.13 & 1.52 & 1.62 \\
\hline \multirow{2}{*}{ Control B } & Scoring rate & $45.83 \%$ & $44.47 \%$ & $49.71 \%$ & $72.70 \%$ & $44.22 \%$ & $42.17 \%$ \\
$\mathrm{~N}=30$ & Mean & 3.77 & 1.33 & 3.89 & 21.81 & 2.88 & 2.65 \\
& S.D. & 1.51 & 0.72 & 1.28 & 6.07 & 1.37 & 0.81 \\
\hline ANOVA & F & 7.04 & 8.02 & 17.52 & 1.36 & 27.52 & 7.12 \\
\hline
\end{tabular}

In order to further understand the differences of teachers' knowledge under different educational probation modes, we continue to use the multiple comparative test of one-way ANOVA to make a two-way comparative analysis of the significant differences of teachers' knowledge among the three classes. The results are shown in Table 3 (because the differences in English knowledge among the three classes are not statistically significant, we have not made an in-depth test on them). The table shows that the performance of the experimental class in each test item is significantly better than that of the two control classes; the control class A is also significantly higher than that of the control class B in educational theory knowledge, English teaching knowledge, and students' knowledge, but there is no significant difference between the two control classes in general curriculum knowledge and English curriculum knowledge.

Table 3

A Pairwise Comparison of Teachers' Knowledge Scores

\begin{tabular}{lllllll}
\hline & & $\begin{array}{l}\text { Educational } \\
\text { theory }\end{array}$ & $\begin{array}{l}\text { General } \\
\text { curriculum }\end{array}$ & $\begin{array}{l}\text { English } \\
\text { curriculum }\end{array}$ & $\begin{array}{l}\text { English } \\
\text { teaching }\end{array}$ & Student \\
\hline \multirow{2}{*}{ Experimental_control A } & S.D. & 2.60 & 6.88 & 3.84 & 3.43 & 2.88 \\
& Sig. & 0.03 & 0.04 & 0.03 & 0.01 & 0.04 \\
\hline \multirow{2}{*}{ Experimental_control B } & S.D. & 3.48 & 6.72 & 3.17 & 3.27 & 2.04 \\
& Sig. & 0.00 & 0.01 & 0.00 & 0.00 & 0.02 \\
\hline \multirow{2}{*}{ Control A-control B } & S.D. & 3.46 & 7.01 & 2.56 & 2.32 & 3.81 \\
& Sig. & 0.05 & 0.08 & 0.68 & 0.03 & 0.05 \\
\hline
\end{tabular}

\section{Discussion}

Result related to research question 1: Educational probation under the tutorial system can effectively improve the English student teachers' knowledge level.

Compared with the non-tutorial system and the routine tutorial system, the tutorial system can help English teachers to master all kinds of teachers' knowledge better. 
In terms of educational theory knowledge, English teaching knowledge, and student knowledge, the order of difference among the three classes is: experimental class > control class A > control class B. In terms of educational theory knowledge, the specialized courses of pedagogy and psychology are offered in the 5th and 6th semesters respectively. During this period, the control class B has not touched the actual middle school classroom. It is unavoidable for them to think that this knowledge is too abstract and of little use. Therefore, subjectively, they do not attach enough importance to these courses and lack the objective conditions for concretizing abstract theoretical knowledge, which makes class B scored the lowest. On the contrary, the experimental class and the control class $\mathrm{A}$, while learning theoretical knowledge, come into contact with the real classroom teaching in middle school. They can concretize abstract knowledge and witness the guiding role of educational theoretical knowledge in practical teaching. They are fully aware of the importance of theoretical knowledge. Therefore, their scores are higher. But compared with the control class A, the performance of the experimental class is better, because they not only have the above subjective and objective conditions, but also teachers' guidance, help, supervision, and opportunities to learn from each other within the group, which will become the driving force of learning, so that they can remember the theoretical knowledge more deeply and grasp it more firmly. This shows that the theoretical knowledge imparting combined with educational practice and teaching situation cannot only stimulate students' interest in learning, but also make students accept the teaching content more effectively. In terms of English teaching knowledge, all three classes have offered the course of Foreign Language Teaching Theory and Practice in the 7th semester. The lowest score is in the control class B. The main reason is that they have only done simulated classroom teaching in the practical part without specific practical environment. The number, language level, and reaction of students cannot represent the real classroom, which is tantamount to building a car behind closed doors. Controlled class A scored higher because they obtained some teaching methods and skills from the teaching of middle school teachers through on-the-spot observation, and completed the simulation classroom teaching according to the real classroom environment. The experimental class has the highest score. In addition to having the same good conditions as the control class A, more importantly, under the guidance of teachers, they have analyzed the middle school English textbook system, made case teaching, and constructed the education system of observation, reflection, attempt, and promotion of reciprocating cycle. Thus, it can be said that only by fully paying attention to the complexity and needs of basic education practice, closely linking pre-service education with basic education, and combining teaching content with students' practical experience, can we effectively generate and improve English teaching knowledge. In terms of student knowledge, the experimental class read some books under the guidance of teachers. At the same time, under the guidance of the instructor, the experimental class paid more attention to the language level, cognitive ability, and memory characteristics of middle school students in the process of probation, which made it possible for them to achieve better results. Control class A also observes the characteristics of middle school students during probation, but this observation is incidental; more attention is paid to teaching methods and teaching processes, while control class B can only understand such knowledge through textbooks. Without referring to the object's character, knowledge is empty and abstract, and not easy to grasp. This results in the highest score in the experimental class, the middle score in the control class $\mathrm{A}$, and the lowest score in the control class B.

In general curriculum knowledge and English curriculum knowledge, the experimental class performed better than the two control classes, while there was no significant differences between the score rate of the two control classes, which indicates that students failed to obtain such knowledge from the professional courses. 
There may be three reasons for this deficiency: First, teacher training does not reflect the needs of the new curriculum, and does not include the curriculum reform outline and curriculum standards of basic education in teacher education curriculum. Second, most college teachers have almost no contact with the teaching of basic education, do not go to school to do on-the-spot investigation and study, do not even know the content of the new course; they are severely disconnected from basic education. Thirdly, subject teaching theory and teaching methods are not keeping pace with the times: The content is not updated in time, and the educational and teaching ideas and methods advocated in the new curriculum standards are not involved. The implementation of the tutorial system makes up for these shortcomings. The tutor not only requires students to read the latest secondary school curriculum standards, but also involves curriculum knowledge in many links, such as case analysis. The integration and infiltration of learning and using enable students to have a certain degree of understanding of curriculum standards and curriculum concepts, which naturally makes the most prominent performance possible.

Accordingly, we believe that the longer the probation time is, the more normal students can understand the real situation of education and teaching at the basic stage and see the gap between their level and the actual needs, which is not only conducive to increasing the motivation of learning, but also conducive to defining the direction of future learning, thus avoiding the confusion caused by the dislocation of ideal and reality in practice and entry. However, the probation time is and students' cognition is limited, so teachers need timely guidance to help students understand the current situation more comprehensively and accurately, and find ways to improve their professional ability. It can be said that the educational probation under the tutorial system is a feasible way to train pre-service English teachers according to circumstances.

Result related to research question 2: The educational probation under the tutorial system makes the development of all kinds of teachers' knowledge relatively balanced.

After a detailed analysis of the scores of the experimental class, we find that the normal school students have achieved good results in all kinds of teachers' knowledge, among which the highest score is English knowledge (72.53\%). It is not difficult to understand that students have been learning English for 10 years. After systematic learning, English knowledge has been internalized to a higher degree, which is also the reason why there is no difference in English knowledge among the three classes.

The other scores were ranked as follows: English curriculum knowledge (63.87\%) > educational theory knowledge $(62.84 \%)>$ general curriculum knowledge $(60.51 \%)>$ student knowledge $(59.11 \%)>$ English teaching knowledge (57.02\%). From the above ranking, it is not difficult to see that the knowledge with a scoring rate more than $60 \%$ is at the memory level, while that under $60 \%$ is at the flexibility and application level. This shows that normal students' mastery of teachers' knowledge is limited within the textbook, and all kinds of knowledge are scattered, independent, not integrated and internalized. The reason for the lower score in student knowledge is that the middle school students of different ages have different learning characteristics, learning styles, cognitive abilities, and language basis. To understand these differences, we need not only theoretical guidance, but also observation in real teaching environment for a long time, and get along with, communicate, and interact with them, which is beyond the reach of normal students. Textbooks and intermittent probation are not enough for normal students to have a comprehensive understanding of the complex and changeable group or individual of middle school students. English teaching knowledge is the core knowledge in the professional development of English teachers. It is generated in the teaching practice of English teachers. It is a comprehensive practical knowledge that integrates educational theory knowledge, curriculum knowledge, 
and English subject knowledge through teaching practice. It needs the accumulation of classroom teaching experience. The richer the teaching practice, the fuller the development of teaching knowledge. Although normal school students have undergone a four-week probation, and have carried out teaching plan design, case analysis, and other work under the guidance of teachers, they have not experienced real teaching practice after all. They cannot attempt and adjust in practice many problems such as how to design teaching strategies conducive to students' learning and how to deal with the difficulties of students' learning in actual classroom. This leads to the lowest score of English teaching knowledge. "The development of English teachers' knowledge is related to the stage of teachers' development” (Liu, 2017, p. 24). Normal students are in the initial stage of teachers' growth. It is good to know all kinds of teachers' knowledge to a certain extent. As for how to use this knowledge comprehensively, only in the long-term concrete teaching practice can they grow up gradually.

From the above analysis, it can be seen that the educational probation under the tutorial system can make the development of all kinds of teachers' knowledge relatively balanced. Although it cannot reach the level of rational use, it can basically meet the needs of English teaching in middle schools. More importantly, the essential qualities of teachers' professional development have been cultivated: first, reflective consciousness. In many activities such as analyzing the actual classroom teaching and revising the teaching plan, the reflective consciousness of normal school students has gradually been developed. Reflection is an effective way for teachers' professional development (Bailey, Curtis, \& Nunan, 2004). It is the key to gradually improve their teaching ability. Only by thorough, meticulous, and continuous reflection on teaching ideas, teaching methods, teaching means, and teaching content in action and after action can they continuously improve the ability of questioning and solving problems, of combining theory and practice, decision-making and teaching situation. Second, the consciousness of independent professional development. Consciousness is a necessary condition to promote professional development (Bailey, Curtis, \& Nunan, 2004). A person who lacks consciousness cannot treat something with his heart. Teachers' awareness of self-development is the attitude and understanding of teachers' continuous efforts in pursuit of better teaching effect. Through probation and group practice, normal students clearly realize that in order to become a good teacher, they must constantly improve their professional knowledge. Only with ideological preparation can normal students actively and actively improve themselves. Third, a strong theoretical awareness. Many scholars believe that the weak theoretical awareness of foreign language teachers and the lack of theoretical guidance in classroom teaching will greatly restrict the improvement of foreign language teaching quality (Shu \& Zhang, 2004; Wang, 2009). The enhancement of theoretical awareness is a prerequisite for the rapid growth of foreign language teachers and the sustainable development of foreign language teaching. The teacher's repeated emphasis on theoretical knowledge and the comparison of teaching effects between different middle school teachers make normal school students deeply aware of the importance of theoretical knowledge, which lays a good foundation for them to continue to strengthen theoretical learning and guide practical teaching with theory in the future.

\section{Conclusion}

Teachers' prior knowledge is an important factor affecting teachers' knowledge level. Pre-service English teachers' knowledge status determines their professional development after entering the post. This study shows that the introduction of educational probation into the tutorial system and the transformation of teachers from the imparters of language knowledge to the instructors, facilitators, organizers, and resource providers of 
teaching practice are helpful to improve the teachers' knowledge level of normal students and the starting point of teachers' professional development. Whether this kind of probation method can enable normal students to acquire more practical knowledge in educational practice and whether it can narrow the gap with in-service teachers in their knowledge will be further explored in future research.

\section{References}

Bailey, K. M., Curtis, A., \& Nunan, D. (2004). Pursuing professional development: The self as source. Beijing: Foreign Language Teaching and Research Press.

Cheng, X. T., \& Sun, X. H. (2010). Problems and challenges in the education and professional development of English teachers in China. Foreign Language Teaching, 3, 1-6.

Liu, L. Y. (2017). Investigation and research on teachers' knowledge level of English teachers in senior high schools. English Teaching and Research in Primary and Secondary Schools, 3, 19-25.

Liu, Y. Q., \& Zou, W. C. (2009). Research on the tradition of excellent foreign language education in East China. Foreign Language Teaching, 4, 33-44.

Ma, Y. P., Zhao, D. C., Han, J. W., Song, X., \& Zhao, X. G. (2008). Investigation and research on the professional knowledge of middle school teachers. Journal of Northeast Normal University (Philosophy and Social Sciences Edition), 6, 57-64.

Shulman, L. (1987). Knowledge and teaching: Foundations of the new reform. Harvard Educational Review, 1, 1-21.

Shu, D. F., \& Zhang, Y. G. (2004). From a survey to the status and role of textbooks in the process of foreign language teaching. Foreign Language Circles, 2, 56-64.

Wang, Q., Tian G. S., Qian X. F., \& Yuan, B. Z. (2007). Research on the education and development of English teachers in Chinese universities. Beijing: Foreign Language Teaching and Research Press.

Wan, M. G. (2005). Research on teacher education curriculum system-Take the construction of teacher education curriculum system in the Faculty of Education of Normal University as an example. Curriculum, Textbooks, Teaching Methods, 7, 83-87.

Wang, S. R. (2009). Summarizing experience, deepening reform, creating a new situation in college foreign language teaching. Foreign Language Circles, 1, 5-8.

Zhang, Y., \& Wang, Q. (2000). Teacher training model and teacher quality: Reflections on the current situation of undergraduate English teaching in normal universities/colleges in China. Foreign Language Teaching, 3, 10-16.

Zhao, X. J. (2006). Reflections on pre-service education of English teachers from the perspective of educational practice: A case study of 2006 graduates' practice of foreign languages college of Inner Mongolia Normal University. Journal of Inner Mongolia Normal University (Educational Science Edition), 19(12), 65-66. 